\title{
Mário de Andrade e Alceu Amoroso Lima - correspondência, (des)harmonia e vida literária
}

\author{
Mário de Andrade and Alceu Amoroso Lima - Correspondence, (anti)harmony and literary life \\ Leandro Garcia Rodrigues \\ Pontifícia Universidade Católica do Rio de Janeiro - Rio de Janeiro - Rio de Janeiro - Brasil
}

\begin{abstract}
Resumo: Este artigo tem o objetivo de apresentar determinados aspectos da troca missivista entre Alceu Amoroso Lima (o Tristão de Athayde) e Mário de Andrade, com particular atenção à problemática envolvendo a questão religiosa, o Catolicismo e a prática da fé, assuntos estes muito debatidos neste epistolário. Neste afã, será utilizada a pesquisa por mim feita e organizada que resultará na publicação futura desta correspondência recíproca pelo Instituto de Estudos Brasileiros (IEB-USP), na Coleção Correspondência Mário de Andrade. Também serão discutido alguns aspectos próprios e relativos do Gênero Epistolar, como sua natureza complexa e amorfa e sua importância, cada vez mais declarada, aos Estudos Literários, particularmente em relação ao nosso processo modernista.
\end{abstract}

Palavras-chave: Epistolografia; Religiosidade; Mário de Andrade; Alceu Amoroso Lima

\begin{abstract}
This paper aims to present some specific aspects concerning the letter interchange between Alceu Amoroso Lima (Tristão de Athayde) and Mário de Andrade, with a particular attention to the problematic discussion about the religious matter, the Catholicism itself and the practice of the faith, subjects widely discussed in this epistolary. In other to do this, we will make use of a certain research by myself concerning this correspondence, done and organized to be published in a future possibility by the Instituto de Estudos Brasileiros, held at Universidade de São Paulo (Brazil), as part of the collection "Mário de Andrade's Correspondence". Thus, we will also talk about some theoretical aspects of the Epistolary Genre itself, as well as its complex nature of performing of expressing, specially within the Brazilian modernist experience.
\end{abstract}

Keywords: Epistolography; Religiosity; Mário de Andrade; Alceu Amoroso Lima

A dinamização dos estudos epistolares, no Brasil, vem trazendo à baila boas surpresas, curiosidades e novas abordagens do nosso processo literário. Não são apenas cartas e outros documentos que são revelados, mas todo o universo (auto)biográfico daqueles diretamente envolvidos na trama epistolar; visão de mundo, aspectos e costumes pessoais, crenças, humor, escrita pessoal e toda a noção de vida literária, categoria esta complexa e sempre expressiva através das suas mais diferentes rachaduras temáticas, ideológicas e estilísticas. Nesta perspectiva, trago à discussão alguns aspectos da correspondência entre Mário de Andrade e Alceu Amoroso Lima (Tristão de Athayde).

A motivação desta empreitada se sustenta na organização que fiz da correspondência recíproca destes dois missivistas, a ser publicada futuramente pelo Instituto de Estudos Brasileiros (IEB-USP), na Coleção Correspondência de Mário de Andrade, coordenada pelos professores Marcos Antônio Moraes e Telê Ancona Lopez.
Devo informar que todos os fragmentos epistolares que cito neste artigo foram retirados deste meu trabalho, ainda sob minha custódia pessoal.

São ao todo cinquenta e quatro (54) documentos (cartas, telegramas e bilhetes) trocados ao longo de dezenove anos, entre 1925 e 19441. A disposição para o

\footnotetext{
Tais documentos foram todos transcritos a partir dos respectivos originais, assim depositados: as cartas de Mário a Alceu estão no Centro Alceu Amoroso Lima para a Liberdade, em Petrópolis (RJ), instituição mantida pela Universidade Cândido Mendes. O outro lado da correspondência as cartas de Alceu a Mário - está sob os cuidados do Instituto de Estudos Brasileiros (IEB-USP). Os documentos de Alceu a Mário estão em excelente estado de conservação, o que facilitou muito a sua transcrição, mesmo a partir de cópias digitalizadas e o posterior cotejamento com os originais. $\mathrm{O}$ mesmo não se pode afirmar em relação às cartas de Mário a Alceu, já que alguns documentos estão em péssimo estado de conservação, de difícil manuseio o que, entretanto, não impede a compreensão final dos mesmos. A transcrição foi feita a partir destes originais e houve comparações daquela com algumas (poucas) cartas publicadas no volume Mário escreve cartas a Alceu, Meyer e outros, organizado por Lygia Fernandes, em 1968. Tal método foi apenas para uma simples conferência, já que os originais - mesmo em estado ruim - possibilitam a leitura de tais textos.
} 
estabelecimento da correspondência foi de Mário, como fica claro na sua primeira carta a Alceu:

\section{São Paulo, 28 de Maio de 1925}

Tristão de Athayde

Confesso que estive pegando um papel bonito pra lhe escrever mas refleti a tempo que isso era indecente. Deixei o tal pra aumentar só o epistolário... rose das damas que me escrevem e voltei pro meu papelinho barato de todo dia com que escrevo aos camaradas. Imensamente the agradeço o artigo que escreveu sobre a Escrava. Li reli repensei aproveitei ${ }^{2}$. O que mais me agrada em você é um dom de penetração quase jesuítico. Nunca vi ler tão bem nas entrelinhas. Já pegando a minha Paulicéia você soube com uma paciência que só mesmo as inteligências muito vivas têm descobrir o que era na realidade aquele livro como expressão psicológica dum autor. Agora com a Escrava ainda foi mais sutil.

Percebe-se claramente que a motivação inicial foi puramente cultural, propondo e realizando aquele tipo de intercâmbio epistolar tão caro aos nossos modernistas, no qual a carta extrapola a sua missão primária de troca de informações e passa a ser uma espécie de "ágora de debates", isto é, a carta se torna parte importante do outro lado da obra, o avesso do texto canonizado e publicado, passando a funcionar como um sintomático reverso não apenas da produção intelectual do artista, mas também da sua própria visão de mundo. Neste sentido, é interessante o que afirmou Gérard Gennete:

Feita essa reserva, podemos utilizar - e é o que fazem os especialistas - a correspondência de um autor (em geral) como uma espécie de testemunho sobre a história de cada uma de suas obras: sobre sua gênese, sobre sua publicação, sobre a acolhida do público e da crítica e sobre a opinião do autor a seu respeito em todas as etapas dessa história. (GENNETE, 1987, p. 316)

Por isso é importante a opinião do destinatário, estabelecendo uma dialogia, sua resposta manterá e ajudará a conduzir o debate, sustentando opiniões e especulações, próprias da amizade. A este contato inicial de Mário, Alceu respondeu meses depois:

\section{Rio, 28 de setembro [1925].}

Meu caro Mário de Andrade

Estou em falta com você. Mas sei que você não repara. E sabe que a minha esquivança e a falta de pontualidade não exprimem desinteresse nem esquecimento. [...] Se algum dia você romper por este Rio e quiser passar alguns momentos longe do tumulto cá de baixo, terei o maior prazer em conhecê-lo pessoalmente. E saberá então que o solene Tristão de Ataíde, gravíssimo Aristarco, que tanto o admira de longe, é o menos literato dos homens.
Pela época - 1925 - Alceu, além de "gravíssimo Aristarco", já era um crítico literário conhecido e respeitado, tendo iniciado sua carreira na Crítica em 1919, em O Jornal, importante periódico carioca conhecido pela qualidade das suas matérias e dos seus articulistas.

Em epistolários como o de Mário e Alceu, as cartas são "pesadas", expandindo ao máximo a tradução desta metáfora, já que se trata de dois correspondentes complexos, com grande formação intelectual e forte sensibilidade artística. Neste afã, um dos assuntos mais discutidos foi a natureza e a permanência do movimento modernista, como Mário declara, na mesma carta de 28 de maio de 1925:

É verdade que essa historiada de modernismo já me caceteia $^{3}$. Não é propriamente que eu hesite entre modernismo e antimodernismo, não, porém faz bem uns dois anos já que principiei a imaginar que a palavra tinha de servir, que a vida dum homem tem coisas muito mais importantes pra resolver que isso de mostrar si o paletó envergado é do último verão ou do próximo inverno ${ }^{4}$. A minha vida é muito bela e muito gostosa pra eu me preocupar de saber se o que escrevo é bem moderno ou não. Modernismo e antimodernismo são palavras que já não têm mais nenhum significado pra mim, juro que não sei mais o que elas querem dizer. Você cuja justeza e independência de pensamento eu respeito me diga se não tenho razão. $\mathrm{E}$ sabe também compreender que estas minhas convicções atuais não significam nenhuma deserção dos meus campos e apenas a compra de mais campos vizinhos. Me

\footnotetext{
2 A respeito deste artigo, assim escreve Carlos Drummond de Andrade a Mário, em carta de 20 de maio de 1925: "O artigo do Tristão de Ataíde sobre a Escrava me pareceu excelente, muito largo de vistas e sem nenhum partidarismo. Admiro profundamente este homem inteligente e honesto." (Carlos \& Mário, 2002, p. 121)

3 Mário utilizou sua correspondência para teorizar e "viver" (sua palavra) o Modernismo brasileiro. Em diversas situações o encontramos eufórico com o movimento, em outros momentos, demonstra certa raiva e insatisfação. Manuel Bandeira foi quem mais ouviu as reclamações do poeta da Paulicéia, como nesta carta de 18 de abril de 1925: "Você compreende, Manuel, eu hoje sou um sujeito que tem muitas preocupações por demais pra me estar amolando com essas burradas de modernismo e passadismo. 'Eu é que sou moderno!' Ora, isso hoje pra mim não significa coisa nenhuma. Tenho mais que fazer. Não estou fazendo blague, não. É uma coisa que está a cem léguas de mim o modernismo. Que significa ser moderno? Ser moderno, ser antimoderno, ora bolas! Sou, isso é que é importante". (Moraes, 2000, p. 201)

4 Esta carta de Mário a Alceu foi motivada após a publicação, em O Jornal, no dia 26 de abril de 1925, do artigo "Modernos II". Neste, Alceu faz uma análise crítica muito positiva do livro A Escrava que não é Isaura. O crítico não poupou elogios a Mário de Andrade, bem como a sua peculiar "evolução literária", bem distinta dos demais "poetas futuristas, cheios de cabotinismos". Alceu assim conclui o seu artigo: "De tudo o que se depreende, sobretudo, é uma necessidade de construir, de procurar novos caminhos, sem abandonar o passado, antes procurando sempre o que há de vivo eterno nele. E isso torna o sr. Mário de Andrade talvez o elemento mais interessante e mais valioso do atual modernismo brasileiro. Sinto que nele se embatem agora modernismo e anti-modernismo. Não no sentido de voltar, mas no sentido de superar." (Lima, 1934, p. 25)
} 
enriqueço ${ }^{5}$. Nada me desinteressa e muito menos o modernismo porém vejo que este em todo o mundo e no Brasil, com algumas exceções apenas está se dissolvendo em vaidades manda-chuvas, partidinhos e sobretudo numa feroz perplexidade. Tendo usado já todas as cocaínas e outros excitantes literários, usado e abusado, o modernismo não sabe mais o que há-de inventar pra chamar a atenção dos desocupados ${ }^{6}$.

É interessante ressaltar que os principais artistas modernistas já revisavam este movimento nos seus primeiros anos de vida, com a criação ou aniquilamento de grupos, com o questionamento ideológico e estético dos caminhos que o Modernismo estava tomando. É nesta perspectiva que compreendemos esta intrigante afirmação de Mário, bem como a rápida e objetiva resposta de Alceu, em 28 de setembro do mesmo ano: "Vivo longe do movimento literário e só tomo parte nele através das minhas crônicas. Não me causam surpresa portanto esses enganos. Nem procuro evitá-los ${ }^{7 ”}$. Alceu usa de uma certa modéstia - um tanto falsa na minha opinião - já que ele viveu intensamente o movimento modernista através da sua crítica especializada, especialmente na sua coluna dominical "Vida Literária", em O Jornal.

Seguindo a questão das "cartas pesadas", que também costumo chamar de "cartas pensadas", Mário e Alceu pensam e analisam os mais diversos aspectos da criação artística, os meandros do ato de escrever; neste aspecto, Alceu foi mais incisivo, como neste fragmento:

\footnotetext{
5 Há pouco tempo da Semana de 22 (apenas três anos), alguns poetas e artistas, como o próprio Mário de Andrade, já faziam algumas revisões críticas dos primeiros anos modernistas. No ano anterior a esta carta, foi fundamental a "Caravana Paulista às Cidades Histórias de Minas Gerais". Nesta viagem, os participantes perceberam a importância da Tradição representada no Barroco mineiro, e que seria difícil (ou pelo menos empobrecedor) uma definitiva ruptura vanguardista ignorando as "lições" do passado. O desafio era evoluir usando as diversas contribuições da nossa Tradição artística.

6 Certamente, Mário faz alusão aos diversos grupos (os "partidinhos") dentro do Modernismo brasileiro, as "panelas literárias", usando uma expressão de Manuel Bandeira. No seu epistolário com Bandeira, Mário sempre se queixava a respeito da falta de caráter de alguns, o que leva Manuel Bandeira confessar a Mário, em 23 de maio de 1924: "Não acredito na amizade na extensão e profundeza em que você a concebe. Amizade: afinidade de inteligências, relação de inteligência. Não quero dizer que seja só isso, que deva ser só isso. Mas que seja sobretudo isso. Confiança? Como confiar em quem amanhã pode ser nosso inimigo? Tenhamos amigos, mas reflitamos: que são como nós carne fraca: não os exponhamos a possivelmente mais tarde magoar-nos. Ajudemos os amigos a desenvolverem harmoniosamente o que há neles de bom. Peçamos o mesmo também a eles." (Moraes, 2000, p. 124)

7 Neste momento da sua vida, Alceu já começara o complexo processo da sua (re)conversão ao Catolicismo através da sua correspondência com Jackson de Figueiredo. Este longo diálogo epistolar teve início em 1919 e foi até 1928, ano da morte de Jackson e do retorno definitivo de Alceu à Igreja. Neste momento da sua correspondência com Mário (1925), Alceu vivenciava o auge da sua crise existencial quanto à existência ou não Deus, quanto à importância ou não da fé, daí a sua reclusão dos círculos mais mundanos da vida literária, conforme afirmado por ele a Mário
}

\begin{abstract}
Rio, 13 de dezembro [1927].
Meu caro Mário

Duas palavras apenas. Em sua casa, e em seu artigo, você perguntava o que é que eu entendia por mística criadora. E eu the respondi, penso eu: "Apenas isto. O sentimento trágico da vida". Não foi isso? Pois bem, na nota tão excessivamente generosa que apareceu sobre o livrinho em Recife, há uma resposta tão idêntica para a mesma pergunta, e que vale como uma interpretação tão exata do que eu penso, que tomo a liberdade de mandá-la a você, para roubar dois minutos do seu tempo. Recebeu o Proust que lhe mandei antes de sair daí? Aqui bastante marasmo. Projetos e nada mais. Livros sem cor nem vida. Verão. E por aí? Ainda muito agradecido pela boa tarde que passei aí em sua casa.
\end{abstract}

Ao receber esta carta, Mário se apressou em responder, dando sintomáticas explicações quanto à sua noção de criação, bem como certas particularidades de algumas das suas obras, tudo no sentido de explicar melhor a Alceu a sua práxis criadora, como se percebe na resposta enviada ao crítico, em 23 de dezembro de 1927:

Minha objeção à "mística criadora" de você continua de pé no caso de não podermos nem devermos parecer com os russos. Acho o caminho russo positivamente ruim e até impossível. Fico abismado até quando vejo tanta gente boa, inteligente criticamente, falar que $O s$ Condenados do Osvaldo parecem Dostoiewski. É tão diferente mas tão que nem posso compreender. Agora, o tal de sentimento trágico da vida existe também nos italianos franceses ingleses alemãs etc etc. E até nos brasileiros, porque não. $\mathrm{E}$ concordo que temos de botar isso nas nossas obras pra torná-las fecundas. Agora, acho que está em muitas delas. É horrível eu ter que falar nos outros por isso deixe eu falar só de $\mathrm{mim}$. Assim posso me atacar e elogiar à vontade, você sabe perfeitamente que isso entre a gente só, não tem importância. Pois, Tristão de Ataíde, você não encontra um só livro meu que seja de deveras alegre. É certo que muitas vezes, talvez a maioria, sou loquaz, tagarela, pândego, gargalhante até. Mas onde que você encontra alegria indiferente, individualista nisso? Está também certo que você encontra em certo e franco dionisismo na minha obra, isto é, não só uma vontade de gozar a vida, porém o gozo da vida, mas justamente no meu livro que você gostou menos, no Losango Cáqui, eu tenho um refrão muito digno de se matutar um pouco sobre ele: "A própria dor é uma felicidade". Porque feliz, isso eu sou.

Relembro e afirmo a importância da epistolografia para se compreender - em diferentes perspectivas - o processo literário brasileiro, particularmente o Modernismo, certamente o período literário mais comentado e discutido na correspondência dos seus principais colaboradores. 
Esta minha opinião é corroborada por Silviano Santiago, que esclarece:

Talvez a maior riqueza que se depreende do exame das cartas de escritores advenha do fato de os teóricos da literatura poderem colocar em questão, desconstruir os métodos analíticos e interpretativos que fizeram a glória dos estudos literários no século 20 . [...] A leitura de cartas escritas aos companheiros de letras e familiares, bem como a de diários íntimos e entrevistas, tem pelo menos dois objetivos no campo duma nova teoria literária. Visa a enriquecer, pelo estabelecimento de jogos intertextuais, a compreensão da obra artística (poema, conto, romance...), ajudando a melhor decodificar certos temas que ali estão dramatizados, ou expostos de maneira relativamente hermética (como a questão da felicidade, em Mário de Andrade, ou a questão do nacionalismo, no primeiro Carlos Drummond). Visa a aprofundar o conhecimento que temos da história do modernismo, em particular do período consecutivo à Semana de Arte Moderna (por exemplo: a reviravolta nacionalista que representa a viagem dos paulistas a Minas Gerais, a expulsão das ideias de Graça Aranha do ideário modernista, as relações entre o intelectual e o Estado na década de 30). (SANTIAGO, 2001, p. 10)

Certamente, Mário e Alceu contribuíram substancialmente para este desvendamento do movimento modernista brasileiro, especialmente analisando e tentando compreender uma dimensão particularmente íntima e complicada de muitos intelectuais e artistas daquela geração: a questão religiosa. Aqui, não quero perceber como tal dimensão aparece ou não nas respectivas obras, ao contrário, quero apenas compreender tal realidade na perspectiva biográfica e ideológica de cada um manifestada nas diversas cartas trocadas.

Já é uma verdade há muito defendida que, na correspondência pessoal, remetente e destinatário se constroem mutuamente. Há uma verdadeira e intrigante "mise en scène" na qual cada um elabora o que deve e pode ser mostrado ao outro do discurso epistolar, existe mesmo todo um código que ajuda na construção deste tipo de comunicação, cujos elementos vão sendo criados e estabelecidos ao sabor do tempo, da tensão das opiniões trocadas, da amizade que se estabelece de forma sincera, dos anseios e angústias trocados nas diversas cartas idas e vindas, enfim, na construção de saberes neste sintomático laboratório de ideologias e estilos que é a epistolografia. O próprio Mário de Andrade reconheceu, na crônica "Amadeu Amaral” (In: $O$ Empalhador de Passarinhos), o valor da correspondência:

Eu sempre afirmo que a literatura brasileira só principiou escrevendo realmente cartas, com o movimento modernista. Antes, com alguma rara exceção, os escritores brasileiros só faziam "estilo epistolar", oh primores de estilo! Mas cartas com assunto, falando mal dos outros, xingando, contando coisas, dizendo palavrões, discutindo problemas estéticos e sociais, cartas de pijama, onde as vidas se vivem sem mandar respeitos à excelentíssima esposa do próximo nem descrever crepúsculos, sem dançar minuetos sobre eleições acadêmicas e doenças do fígado: só mesmo com o modernismo se tornaram uma forma espiritual de vida em nossa literatura. (ANDRADE, 2002, p. 187)

Neste sentido, as opiniões de cada um são expostas na arena da convivência missivista, concordâncias e discordâncias são postas à luz gerando tensões próprias da experiência humana e registradas na narrativa epistolar. Desta forma, o papel e o distanciamento geográfico funcionam como antídoto, possibilitando uma maior sinceridade que, muitas vezes, a relação pessoal e presencial inibe, desencoraja. Toda esta complexidade da doação de si próprio pode ser verificada na correspondência entre Mário de Andrade e Alceu Amoroso Lima, especialmente no que concerne às ideologias e debates acerca da religiosidade, particularmente o catolicismo, principal assunto discutido e problematizado neste epistolário.

Mário encontra em Alceu um interlocutor à altura das suas dúvidas religiosas e existenciais, um intelectual com o qual se podia travar um belo debate, aprofundado, alguém com algo a dizer. Já Alceu via em Mário um grande talento artístico que podia ser melhor compreendido nestas questões e, quem sabe, arregimentado de forma definitiva ao seio da renovação espiritual pela qual boa parte da intelectualidade brasileira estava passando naquele momento. Ou seja, é uma troca equilibrada de relações, na qual um não se sobrepõe ao outro, não existindo entre eles nenhuma relação mestre/discípulo, ninguém doutrinou ninguém, apenas dialogaram com um forte teor de argumentação. Nesta carta de 14 de julho de 1929, Mário fez sintomáticas revelações:

\section{S. Paulo, 14-VII-29}

Alceu,

Talvez devido às amarguras, eu tenha exagerado um pouco o meu estado-de-espírito de agora. Nada de fundamental se modificou em mim e se você me permite chamar de "catolicismo" que sempre tive, continuo tendo. Não sei nem me deitar nem levantar sem essa carícia pra Deus e os nossos intermediários que é a reza ${ }^{8}$. É certo que estou no momento atual

\footnotetext{
8 Em 5 de março de 1939, Mário publicou, no Diário de Notícias, a crônica "Começo de Crítica", da qual extraímos a seguinte passagem que esclarece um pouco a sua concepção sobre Deus: "Creio em Deus, tenho essa felicidade. E jamais precisei de provas filosóficas para crer. Deus é uma espécie de constância do meu ser (não se dará o mesmo com todos?...), eu O sinto na ponta do meu nariz. Mas se trata de uma entidade verdadeiramente sobre-humana, que a minha inteligência não consegue alcançar, de uma grave superioridade silenciosa. Isso, aliás, se percebe muito facilmente no sereno agnosticismo em que descansa toda a minha confraternização com a vida. Deus jamais não me prejudicou a minha compreensão dos homens e das artes." (ANDRADE, 1993, p. 13)
} 
numa irritação muito forte. Mas não é contra o Catolicismo. É principalmente contra os católicos. Os porquês são muito longos e já são vinte-e-quatro horas deste meu último dia de férias. Mas você também háde sentir que existe hoje uma "moda católica" que, profícua ou não pros almofadinhas dela, há-de irritar com nitidez um espírito como o meu9 . Minha produção si tem sido especialmente acatólica, pode ter certeza que é pela discrição sensibilizada com que me sinto na impossibilidade de jogar uma coisa pra mim tão essencial e tão elevada como a religião dentro dessas coisas tão vitais, terrestres e mundanas como as artes. Por isso apenas me limitei a respeitar uns gritos de sincero religioso e amarguras que saíram em versos e prosa minha. Na Paulicéia o "Religião"10, a imitação do salmo de Davi e o que a circunda no "Carnaval Carioca" $"$, as páginas amargamente irônicas sobre o catolicismo tradicional da família Sousa Costa no “Amar, Verbo Intransitivo" e quase que só.

Aqui Mário revela o ponto central da sua espiritualidade pessoal: acredita em Deus mas tem desgosto pela religião, isto é, crê no religare com o Sagrado, com o transcendental professado pelas religiões, mas permanece adogmático e não aceita as sanções próprias de qualquer sistema religioso. Tal forma pessoal de lidar com o Sagrado é deveras tenso, rachado, poroso e instável. Diplomático, Alceu respeita a opinião do amigo e escapa ao aprofundamento do debate, porém fornecendo boas razões, como se percebe na sua resposta:

Rio, julho, 17 [1929]

Mário

Tenho muito escrúpulo em entrar no assunto, ou antes no tema geral, que provoca atualmente o seu estado de irritação, menos contra o catolicismo que contra os católicos. Bem sei quantos temas há hoje nestas condições e quanto essas discrepâncias precisam de tempo, de meditação e de boa vontade para ser resolvido.

Gostaria de trocar ideias com você a respeito, menos pelo fato em si, que permite evidentemente, uma grande liberdade de interpretação e não compreender nenhuma matéria estritamente dogmática, ou mais pela posição qual do seu pensamento, de uma atitude, não somente quanto os católicos, mas sobretudo quanto o catolicismo. Estamos em um momento tão grave da nossa vida nacional e de nossa carreira individual que precisamos olhar a fundo esses problemas por vezes tão dolorosos e angustiantes.

Não quero, porém, abusar de sua confiança e acanhar e preocupar a quem talvez no momento não deseja ou possa dedicar tempo a esses problemas. Eu mesmo sei que não tenho qualidade, e sobretudo capacidade alguma para tratar disso, e que, no seu caso, o trabalho terá de ser interior, com a graça especial de Deus que até hoje nunca lhe faltou de todo. Abstenho-me, por isso, de entrar diretamente no que na carta tem de mais geral, reservando-me para o fazer algum dia, ou já, se você julgar oportuno.

Você bem sabe que nós, católicos não de moda mas de convicção e de drama interior, não podemos nunca nos recusar a debater esses problemas que são, para nós, de vida ou $\underline{\text { morte }}^{12}$.

Limito-me a mandar-lhe algumas palavras que pronunciei recentemente e que você talvez queira contestar mais precisamente, por carta, se acaso se dispuser a entrar no assunto. Eu por mim, respeito demais a você e a seu pensamento - quer para passar adiante, deixando esse problema irresolvido, quer para ser indiscreto. Você dirá.

9 Mário não estava exagerando ao fazer alusão a uma certa "moda católica" na sociedade brasileira. De fato, no final dos anos 20, a Igreja Católica no Brasil sentiu um forte impulso na sua atuação junto à sociedade. $\mathrm{Na}$ verdade, a Igreja tentava recuperar o espaço perdido após a Proclamação da República, fase na qual ela foi vítima de um forte sentimento anticlericalista, em virtude do Positivismo e do Comunismo exagerados daqueles tempos. A partir dos anos 20, o governo brasileiro se viu "vítima" das suas próprias convicções não-religiosas - o avanço sem controle das ideologias comunistas. A solução encontrada foi propor uma "relação de cooperação" com a Igreja Católica, momento a partir do qual a instituição passou a atuar mais intensamente em diversos setores da sociedade, principalmente na Educação. Multiplicaram a quantidade de colégios e faculdades católicas, organizou-se uma imprensa católica com expressiva força, especialmente com a criação de revistas, livrarias e editoras diretamente ligadas à Igreja. Todo esse movimento culminou, em 1932, com a implantação da Ação Católica Brasileira, movimento religioso que propunha uma maior atuação do leigo católico na sociedade, através de associações e órgãos formadores de opinião. Certamente, a "moda católica" citada por Mário de Andrade diz respeito a todo este contexto histórico-cultural-religioso do qual Mário foi um ferrenho opositor. (Cf. RODRIGUES, Leandro Garcia. Alceu Amoroso Lima: Cultura, Religião e Vida Literária. São Paulo: EDUSP, 2012.).

10 Assim começa o poema "Religião", publicado em Paulicéia Desvairada: "Deus! Creio em Ti! Creio na tua Bíblia! / Não que a explicasse eu mesmo, / Porque a recebi das mãos dos que viveram as iluminações! [...]" (ANDRADE, 1993, p. 100).

11 Certamente, Mário se refere à seguinte passagem do seu poema "Carnaval Carioca": "Aleluia! / Louvemos o Criador com os sons dos saxofones arrastados, / Louvêmo-Lo com os salpicos dos xilofones nítidos! / Louvemos o Senhor com os riscos dos recorrecos e os estouros do tantã, / Louvêmo-Lo com a instrumentarada crespa do jazzband! / Louvêmo-Lo com os violões de cordas de tripa e as cordeonas imigrantes, / Louvêmo-Lo com as flautas dos choros mulatos e os cavaquinhos de serestas ambulantes! / Louvemos O que permanece através das festanças virtuosas e dos gozos ilegítimos! / Louvêmo-Lo sempre e sobre tudo! Louvêmo-lo com todos os instrumentos e todos os ritmos!... [...]" (ANDRADE, 1993, p. 169). Com este tipo de criação, percebemos uma forte intertextualidade com os salmos bíblicos do Antigo Testamento. Vale lembrar que a Salmonística foi um gênero muito utilizado na Antiguidade, especialmente na criação de orações salmos - que expressavam as mais diferentes situações da vida: pedido de auxílio, ação de graça, penitência etc. Mário claramente dialoga com um salmo de ação de graças, todavia, inclui elementos culturais (musicais) típicos do seu contexto cultural, num claro processo de Antropofagia cultural.

12 Alceu desenvolveu esse tipo de debate na sua correspondência com Antônio de Alcântara Machado, reunida no volume Intelectuais na Encruzilhada (Academia Brasileira de Letras, 2000), organizada por Francisco de Assis Barbosa. Neste epistolário, Alceu discute e analisa a postura cética de Alcântara Machado em relação à religião católica e, especialmente, na importância de se ter uma fé. Entretanto, a postura de Alceu não foi de tentar (re)converter Alcântara ao Catolicismo, justamente o contrário do que ocorrera na sua correspondência com Jackson de Figueiredo. 
Alceu fez uma afirmação que considero complexa e cheia de possíveis compreensões: "Você bem sabe que nós, católicos não de moda mas de convicção e de drama interior, não podemos nunca nos recusar a debater esses problemas que são, para nós, de vida ou morte." Para Alceu, ser católico não era uma opção confortável, ao contrário, era uma espécie de exercício interior e deflagrador de crises existenciais, dúvidas, questionamentos, ou seja, a experiência da fé era também a experiência da descoberta, da busca, da ânsia em relação a Deus, da sede pelo Infinito - tudo isso metabolizado numa constante luta com o mundo moderno, secularizado, ateu ou agnóstico, antireligioso em muitas manifestações, daí a noção de "drama interior".

Décadas depois, após um longo hiato na Correspondência, Mário e Alceu voltaram a discutir esta mesma problemática, com Mário se expressando de forma mais ácida e profundamente cético em relação à necessidade da religião na sua vida, mas sempre afirmando a sua crença em Deus, de forma subjetiva, íntima e procurando "sentir" Deus numa perspectiva toda pessoal, até mesmo um tanto ontológica, como se percebe nesta carta a Alceu, em 17 de junho de 1943:

Sim: o Catolicismo é muito maior que você e vocês todos católicos. Mas o Catolicismo tem esse, pelo menos, perigo de ser além de uma Ideia, uma religião. Vocês têm de pôr a ideia em ação. E é dentro desta Ideia em ação que com todos os padres que cercam você, bem ou mal intencionados, úteis ou nefastos; com todos os fiéis que admiram você e aceitam preliminarmente as suas pregações; com todos os moços safados de carne que se torturam no espírito e a que você dará suavização e o sabor católico de uma rápida paz; com todas as boas ações, atos de caridade ocultos, esmolas escondidas que você possa fazer: é dentro dessa Ideia em ação que eu não aceito você. Que você me irrita. Que você me afasta porque não quer me atingir. Você e a "religião", a coletividade terrestre que guarda a Ideia católica.

Em todo o seu epistolário com Alceu Amoroso Lima, este é o fragmento mais duro, onde o autor de Remate de Males se mostra mais irredutível quanto à ideia de que ser religioso não é ruim, mas ter uma religião é problemático. Quando ele afirma que "Catolicismo é muito maior que você e vocês todos católicos" está justamente corroborando esta premissa. Mário não compreendia a religião na perspectiva de combate, como queria Alceu e muitos outros, mas buscava a noção básica do religare, isto sim dava-lhe sentido, como ele deixa claro nesta passagem da mesma carta:

A civilização vai mudar, Tristão. A Civilização Cristã chamada, e que não sei se algumas vezes $\mathrm{V}$. não confunde um bocado com Cristo, está se acabando e vai ser um capítulo da História ${ }^{13}$. Tão lindo como o dessas igualmente nobilíssimas civilizações da Antiguidade, o Egito, a China, a Grécia. Com a Cristã nós demos um passo a mais, apenas um passo a mais do amilhoramento terrestre do homem e da sociedade humana. Se nem tudo foi pra melhor, o todo foi incontestavelmente pra melhor. E a civilização que vem ainda há-de ser fatalmente um passo a mais, e um todo melhor. Tudo isto nada tem que ver com o outro mundo. Nem eu sei nem quero a morte da Igreja imortal e o desaparecimento da religião nem a sempre por demais próxima chegada do Anticristo. Mas não haverá o perigo pra muitos e pra você, de preferir a Igreja a Deus? Eu não ignoro não os perigos dos meus argumentos para o meu para-catolicismo ${ }^{14} \mathrm{em}$ que me debato. Serão argumentos do Diabo. Ou serão argumentos do orgulho. Mas eu quero bater a uma porta mas essa porta não pode se abrir porque os que estão lá dentro não podem interromper o Te-Deum. Então eu solto um grande grito pra Deus me escutar.

13 Esta expressão - civilização cristã - foi muito utilizada em todo o programa de "recristianização" do Brasil pretendida pela Ação Católica Brasileira, especialmente nos seus primeiros anos, tendo Alceu como o seu presidente nacional. Na verdade, havia um certo tom nostálgico e defensivo da noção de civilização cristã, tendo sempre a sociedade medieval como paradigma de domínio e influência católicos. Neste sentido, Mário fez um longo comentário no seu exemplar de Mitos do Nosso Tempo, de autoria de Alceu, no capítulo V, p. 52-53: “Aqui, a tese me parece que se fragiliza por completo. Na realidade, o Alceu não está mais estudando e julgando enquanto filósofo e sociólogo, mas em função do seu catolicismo. De um catolicismo que julga a chamada (meu Deus!) 'Civilização Cristã' como tendo alcançado o seu apogeu na Idade Média. Isto é: uma civilização, não mais definida e compreendida pelo que é, em si, mas como expressão da doutrina de Cristo. Ora, não há dúvida que o Cristianismo, ou melhor, Cristo, deu origem a uma civilização. Mas da qual, em seguida, ele não teve a culpa. Negar o Renascimento, por exemplo, como uma das expressões máximas da Civilização Cristã é simplesmente confundir civilização e cultura (Kultur, sociologicamente) com uma determinada religião. Não é tudo. Se observarmos outras civilizações (depois desta frase do Alceu), a grega, por ex. ou a chinesa, vemos que certos 'mitos' por ele enumerados foram princípios básicos não da 'desintegração’ dessas civilizações, mas dos períodos de formação e plenitude. A ‘classe' por ex. na Grécia. A 'cultura' na China”. (Instituto de Estudos Brasileiros - USP, Biblioteca Mário de Andrade).

Com a passagem do tempo e o consequente amadurecimento, Alceu modificou sobremaneira a sua opinião sobre a unicidade católica ocidental, chegando mesmo a rejeitar a noção de cristandade e/ou civilização cristã para classificar a sociedade contemporânea. Tal mudança pode ser percebida nesta afirmação, nas suas Memórias Improvisadas, espécie de balanço memorialístico da sua vida: "Por isso mesmo é que, longe de ser uma instituição de Idade Média, como pretendeu Augusto Comte, e tantos opinam mesmo entre os fiéis, ela é de fato uma instituição da Idade Nova. [...] Não creio, mesmo, que se deva mais falar em civilização cristã. E sim na presença do Cristianismo ao longo das civilizações. O Cristianismo esteve presente na civilização burguesa e se envolveu demais com ela. Estará presente na civilização proletária ou que nome venha a ter, e deverá cuidar de não se deixar envolver demais por ela, como já o fez com a civilização burguesa, depois que o fizera com a civilização feudal da Idade Média e com a civilização monárquica, absolutista ou liberal pós-renascentista.” (LIMA, 1973, p. 266)

$14 \mathrm{O}$ escritor usa constantemente este termo - para-catolicismo - para designar uma espécie de "catolicismo paralelo", ou seja, um sentimento católico que ainda permanecia em Mário devido à sua formação e criação, porém era uma simples permanência quase que como uma "lembrança", e não como "prática de um credo", isto ele sempre deixa bem claro nas cartas não apenas a Alceu, mas a todos os seus correspondentes que tocavam neste assunto. 
E como eu "quero" que Ele me escute, Ele me escuta. Mas ainda não pude saltar o grande grito e me sinto sozinho. Porque os que deviam vir a mim porque eu não vou a eles, não vêm até mim. E eu não sei si há-de haver tempo para eu saltar o grande grito.

Mais uma vez, Mário deixa claro a Alceu que ele também tinha a sua "busca", não no sentido de conversão, mas no sentido de religar-se ao Divino: "Então eu solto um grande grito pra Deus me escutar. E como eu "quero" que Ele me escute, Ele me escuta". Mário tinha clareza da presença de divindade na sua vida e no seu eu, ele não estava só (como sempre repetia a Alceu), simplesmente tinha liberdade de não querer institucionalizar esta presença.

Sempre conciliador e tentando apaziguar os ânimos do polígrafo paulista, Alceu Amoroso Lima replicou a esta raivosa carta de Mário de Andrade, apresentando a sua interpretação a respeito da mesma, como se percebe na sua resposta de 24 de junho de 1943 :

Petrópolis - 24 - junho [1943]

Sim, meu caro Mário, é sempre tempo de você soltar "o grande grito". A despeito da sua confessada "incompreensão", a despeito das suas raivas pessoais, a despeito de tudo o que sua carta revela contra nós e contra mim, particularmente, estou mais junto de você do que você pensa.

Você não gostou do meu livro porque achou "pouco" sectário. É a posição frequente de quem só sente a Verdade por fora. Uma vez dentro dela, uma vez dado o grande passo, tudo aquilo que lhe parece capital - restou zunindo no lombo dos infiéis, sectarismos, polêmicas, brigas, descomposturas - tudo passa a ser exclusivamente relativo ao temperamento individual de cada um. [...]

Quanto ao meu livro, não posso evidentemente forçar você a compreendê-lo. Tanto mais quando você confessa que não faz questão de ser justo em crítica, e que está escrevendo com raiva. Agora, o que é falso e mostra que você não leu bem o livro, é que eu digo que é preciso preliminarmente crer para aceitar as conclusões. Bem mais justo foi o Plínio Barreto ${ }^{15}$ quando, em sua crítica, afirmou que tudo aquilo que eu ali digo pode ser aceito por quem não tem fé.

É o oposto do que você diz. E como ele tem a preocupação (às vezes exagerada) de ser fiel ao autor, acredito que ele e não você que tem razão. Se algum dos seus jovens amigos lhe deu essa impressão é que também, como você, é um sectário. Ora, com sectários não é possível discutir, nem em particular. Se você se encastela nas suas afirmativas dogmáticas e não quer ouvir razões, para quê discutir? Você é enraivecido. Fica brabo comigo porque eu não sou bastante brabo. Depois, fica também danado porque o meu livro é "afirmativo" demais. Em que é que ficamos? Você se contradiz a cada passo. Aliás, como toda alma "com raiva". Você diz que o Cristianismo "morreu". Uma forma de Cristianismo sim. Mas não o Cristianismo. Na civilização de amanhã, que será socialista como a de ontem foi liberal, o lugar da Igreja e do Cristianismo será o mesmo. Não mais como na Idade Média, mas numa posição tão inabalável, no fundo, como então ${ }^{16}$. Eu mais que você tenho raiva dos que vivem "cantando Te Deum". Meu livro se dirige aos que creem, como aos que não creem. Vivo falando, escrevendo, trocando causos, discutindo em público ou não (pois a minha afirmativa de que não discuto em público é apenas para dizer que considero inúteis as polêmicas e acho que chegamos hoje a um momento em que construir vale mais do que destruir) - vivo fazendo tudo isso porque vivo ansiando pelas almas, vivo angustiado com os que não veem como eu cheguei a ver, vivo procurando tocar o coração dos infiéis, mais do que o seu lombo. Neste ponto você tem razão. Eu poderia chegar agora, com raiva de sua carta e deixar você "gostando", como diz o vulgo, ou sair em público e dizer que você é um incorrigível pedante ou um anacoreta que se ignora ou um falho comunista ou um intelectual disfarçado a contar com a força para os seus adversários - enfim, poderia sair "zunindo" como você diz. É possível que certas almas fracas gostassem de mim e viessem para a Igreja por causa disso. São como certas mulheres

15 Plínio Barreto (1882-1958). Advogado, jornalista e crítico literário do jornal O Estado de São Paulo. Em 1928 teve uma forte desavença ideológica, via imprensa, com Jackson de Figueiredo, aludida em carta a Alceu, de 14/01/29. Pelo teor da mesma, Jackson criticou certas simpatias de Plínio pelo Comunismo, expressas em seus artigos no referido jornal paulista. Plínio fundou e foi o primeiro presidente da OAB - São Paulo, em 1932. Exerceu uma forte participação político-intelectual através do Estadão, especialmente durante o Movimento Constitucionalista. A partir de 1933, por convite de Júlio Mesquita Filho, tornou-se diretor de $O$ Estado de São Paulo.

${ }^{16}$ Ainda voltando ao exemplar de Mário de Mitos do Nosso Tempo, vêse claramente a indignação de Mário de Andrade reclamada por Alceu. No capítulo XV, páginas 190-191, temos um longo trecho destacada por Mário: "Aqui desejo apenas acentuar que o pan-eslavismo, que se desenvolveu a partir de certa fase da Revolução Soviética ou antes que se integrou na Revolução Comunista, formando com ela uma estranha simbiose, na base de um messianismo ao mesmo tempo racial e institucional - o pan-eslavismo está hoje confundido com o sovietismo. Mas possui um caráter essencialmente racista e muito anterior ao do germanismo hitlerista, que só o assumiu em fase relativamente recente da sua Revolução." Não concordando com tais argumentos históricos usados pelo autor, Mário fez um longo comentário através do qual lançou sua amarga opinião a respeito das ideias de Alceu: "Aqui a injustiça da generalização chega ao absurdo, a não ser que o Alceu esteja mentindo - o que talvez seja preferível imaginar. Dar ao sovietismo 'caráter essencialmente racista' e o que é mais idiota pan-eslavista, ou confundir com o pan-germanismo racista, que o Alceu insiste em justificar (é o termo doloroso) como nascido de uma necessidade contra a Revolução, quando ele mesmo lhe reconhece causas de origem histórico-psicológicas: tudo isso é confundir atualidade histórica com falsa profecia. Profecia falsa que nem os dados da Espanha, da China, do México justificam siquer. De resto, o mal demagógico infelizmente revestido de Cristianismo ou simplesmente de Filosofia, de toda a pregação idealista desta parte, é que o Alceu não enxerga o homem, mas sonha com o Homo. E o que é mais idílico, mas apenas idílico, um Homo dotado de historicidade, um sonho do Homo pré-renascente, pré-rafaelista, ao mesmo tempo que esquece toda a história do homem anterior a Cristo e posterior à Civilização Cristã. Nunca o Alceu abusou tanto da Verdade e da filosofia pra criar um sonho não apenas improvável: absolutamente vão." 
que gostam de pancada. Mas eu prefiro não proceder assim. Minha natureza não me aconselha a fazê-lo. Procurando mesmo olhar para Jesus Cristo, vejo que

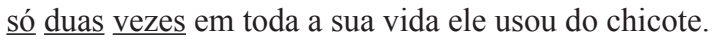

Poderia elencar outros fragmentos que sustentam este debate tão intrigante entre o crítico e o escritor, entre estes dois grandes ecos do nosso Modernismo, já que a briga em torno da questão religiosa foi intensa e cheia de outras diferentes (contra)argumentações. Todavia, por uma opção puramente metodológica (limite de espaço do próprio artigo), opto aqui em deixar aos interessados a futura leitura da Correspondência recíproca entre Mário de Andrade e Alceu Amoroso Lima que, como afirmei no início deste ensaio, é planejado que seja publicada em breve.

Tudo isto confirma e ilustra bem o interesse de Mário pelo debate de ideias, pela construção de saberes os mais ideologicamente díspares. Neste afã, Alceu Amoroso Lima foi um correspondente à altura, já que a grandeza de espírito e a inteligência eram proporcionais em ambos, eram "grandes" nas atitudes e na ideologia, o que forneceu uma interlocução epistolar de alto nível e profunda complexidade.

Daí afirmar-se que a religião, ou pelo menos o discurso religioso, estava envolvido e/ou problematizado na vida literária, nas relações pessoais e na produção intelectual e artística. Por isso, a importância desta correspondência entre Mário de Andrade e Alceu Amoroso Lima, já que a mesma se mostra intensa quanto aos debates e especulações a respeito da fé e da religiosidade de ambos - Mário e Alceu - estes dois grandes nomes da cultura brasileira que fizeram diferentes e sintomáticas leituras do Brasil.

Ao fazer a leitura completa das 54 cartas trocadas entre Mário de Andrade e Alceu Amoroso Lima, percebemos que a mesma não foi usada - em sua totalidade - para marcar um certo tom uníssono de ideias pessoais e opiniões. A bem da verdade, em alguns momentos, ambos usam a carta para elogios e admirações recíprocos, especialmente quando Mário vê em Alceu o protótipo do crítico literário ideal, ou então quando Alceu percebe em Mário o cerne do equilíbrio criativo e estético entre tradição e vanguarda, como ele próprio afirmou várias vezes. Mas o principal teor desta correspondência é a marcação das diferenças, das descontinuidades ideológicas, principalmente em relação à natureza da religião e à prática da fé. É exatamente o que Vincent Kaufmann chamou de "equívoco epistolar", ou seja, em vez de funcionar como uma espécie de aproximação dos espaços, a escrita epistolar também pode produzir um sintomático distanciamento, pois "desqualifica toda forma de partilha e produz uma distância graças à qual o texto literário pode sobrevir, fragmentos de vida muito escritos para uns, textos muito pouco textuais para outros" (KAUFMANN, 1990, p. 8).

Mário e Alceu, o primeiro vivendo na incerteza da busca, o segundo proclamando a certeza desta mesma busca. Em linhas gerais, uma dramática e tensa tentativa de união dos contrários, de harmonia das diferenças.

\section{Referências}

ANDRADE, Carlos Drummond de \& ANDRADE, Mário de. Carlos \& Mário - Correspondência completa entre Carlos Drummond de Andrade e Mário de Andrade. Organização e pesquisa iconográfica de Lélia Coelho Frota. Rio de Janeiro: Bem-Te-Vi, 2002.

ANDRADE, Mário de. Aspectos da literatura brasileira. São Paulo: Livraria Martins, 1972.

ANDRADE, Mário de. Mário de Andrade escreve cartas a Alceu, Meyer e outros. Rio de Janeiro: Editora do Autor, 1968.

ANDRADE, Mário de. O empalhador de passarinho. Belo Horizonte: Itatiaia, 2002.

ANDRADE, Mário de. Vida literária. São Paulo: EDUSP/ HUCITEC, 1993.

AZZI, Riolando. História da igreja no Brasil - terceira época 1930-1964. Petrópolis: Vozes, 2008.

FERNANDES, Cléa Alves de Figueiredo. Jackson de Figueiredo - uma trajetória apaixonada. Rio de Janeiro: Forense Universitária, 1989.

GALVÃO, Walnice Nogueira. “À Margem da Carta”. In: Desconversa (Ensaios criticos). Rio de Janeiro: Editora da UFRJ, 1998.

GOMES, Ângela de Castro. Essa gente do Rio... - modernismo e nacionalismo. Rio de Janeiro: Fundação Getúlio Vargas Editora, 1999.

GUIMARÃES, Júlio Castañon. Contrapontos: notas sobre correspondência no modernismo. Rio de Janeiro: Fundação Casa de Rui Barbosa, 2004.

GUIMARÃES, Júlio Castañon. Distribuição de Papéis: Murilo Mendes escreve a Carlos Drummond de Andrade e a Lúcio Cardoso. Rio de Janeiro: Fundação Casa de Rui Barbosa, 1996.

KAUFMANN, Vicent. L'equivoque Épistolaire. Paris: Éditions de Minuit, 1990.

LIMA, Alceu Aamoroso. Affonso Arinos. Rio de Janeiro: Civilização Brasileira, 1922.

KAUFMANN, Vicent. A estética literária e o crítico. Rio de Janeiro: Livraria Agir Editora, 1954.

KAUFMANN, Vicent. Memorando dos 90. Rio de Janeiro: Editora Nova Fronteira, 1984.

KAUFMANN, Vicent. Memórias improvisadas - diálogos com Medeiros Lima. Petrópolis: Vozes, 1973.

KAUFMANN, Vicent. Notas para a história do Centro Dom Vital. Rio de Janeiro: Educam/Paulinas, 2001. 
LIMA, Alceu Amoroso; FIGUEIREDO, Jackson de. Correspondência - harmonia de contrastes, Tomos I e II. Rio de Janeiro: Academia Brasileira de Letras, 1991.

LOPEZ, Telê Ancona. Táxi e Crônicas no Diário Nacional. São Paulo: Duas Cidades, 1976.

MORAES, Marcos Antônio. (Org.). Correspondência Mário de Andrade \& Manuel Bandeira. São Paulo: EDUSP, 2002.

MORAES, Marcos Antônio. Orgulho de jamais aconselhar - a epistolografia de Mário de ANDRADE. São Paulo: EDUSP/ FAPESP, 2007.

RODRIGUES, Leandro Garcia. Alceu Amoroso Lima - cultura, religião e vida literária. São Paulo: EDUSP, 2012.
RODRIGUES, Leandro Garcia. Uma leitura do Modernismo cartas de Mário de Andrade a Manuel Bandeira. Dissertação de Mestrado. Rio de Janeiro: Pontifícia Universidade Católica do Rio de Janeiro, 2003.

SANTIAGO, Silviano. "Suas cartas, nossas cartas". In: ANDRADE, Carlos Drummond de \& ANDRADE, Mário de. Carlos \& Mário - correspondência completa entre Carlos Drummond de Andrade e Mário de Andrade. Organização e pesquisa iconográfica de Lélia Coelho Frota. Rio de Janeiro: Bem-Te-Vi, 2001.

Recebido: 29 de outubro de 2013 Aprovado: 02 de janeiro de 2014

Contato: prof.leandrogarcia@hotmail.com 